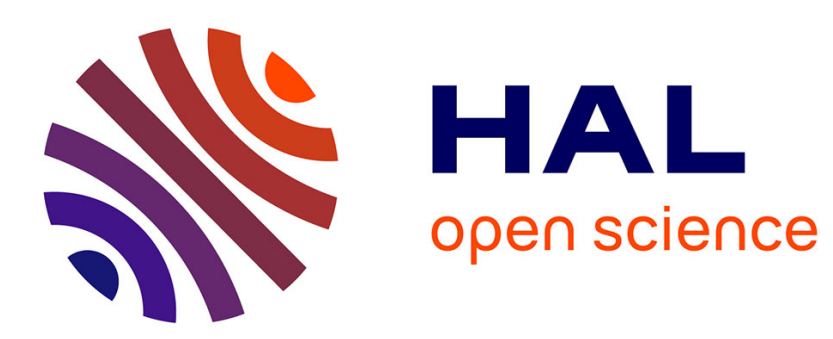

\title{
GEWINNFUNKTIONEN - EIN HILFSMITTEL FÜR DIE PLANUNG VON GEBRAUCHSKREUZUNGEN BEIM SCHWEIN
}

\author{
F. Fewson, V. Jakubec
}

\section{> To cite this version:}

F. Fewson, V. Jakubec. GEWINNFUNKTIONEN - EIN HILFSMITTEL FÜR DIE PLANUNG VON GEBRAUCHSKREUZUNGEN BEIM SCHWEIN. Annales de génétique et de sélection animale, 1971, 3 (1), pp.101-102. hal-00892425

\section{HAL Id: hal-00892425 \\ https://hal.science/hal-00892425}

Submitted on 1 Jan 1971

HAL is a multi-disciplinary open access archive for the deposit and dissemination of scientific research documents, whether they are published or not. The documents may come from teaching and research institutions in France or abroad, or from public or private research centers.
L'archive ouverte pluridisciplinaire HAL, est destinée au dépôt et à la diffusion de documents scientifiques de niveau recherche, publiés ou non, émanant des établissements d'enseignement et de recherche français ou étrangers, des laboratoires publics ou privés. 


\title{
DEVELOPMENT OF THE COEFFICIENT OF INBREEDING AND RELATIONSHIP IN THE FINNISH AYRSHIRE BREED.
}

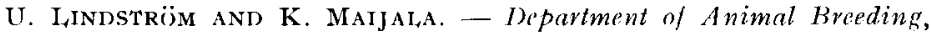 \\ Agricultural Reseavch Centre, Tikkurila, Finland.
}

On the basis of samples of cows taken from the herd hook (4-lines pedigrees carried back to 1894-97) and on pedigree information (7 generations) for AI bulls the level of inbreeding and relationship in the Finnish Ayrshire breed was studied. By year of birth, samples of 50 cows were taken for each of the years $1915,-25,-35,-45,-55$ and -60 as well as a sample of 100 cows for the year 1965 . The 783 AI bulls analysed were born between 1939 and 1962 .

The coefficient of relationship rose from $2.0 \pm 0.5$ per cent in 1915 to $7.3 \pm 0.6$ per cent in 1965 and has, in the period 1945-65, remained at the same level. Over the whole period studied the coefficient rose, on an average, 0.77 per cent/generation, i. e. 0.1 à 1 per cent/year.

The coefficient of inbreeding $\left(\mathrm{F}_{x}\right)$ rose from $1.2 \neq 0.4$ per cent in 1915 to $3.2 \pm 0.4$ per cent in 1965. Up to 1935 the observed coefficients were in agreement with those expected on the basis of the degree of relationship. In the following 20 years period the observed $F_{x}$ values were some 2 per cent units lower than the expected ones. Over the whole period studied the coefficient rose, on an average, $0.34 \mathrm{per}$ cent/generation, i. e. $0.05 \mathrm{per}$ cent/year.

The Scottish ancestors' proportion of the genes increased from 65 per cent in 1915 to 92 per cent in 1965. On an average the earlier importations accounted for 59-72 per cent of the genes. Those imported in 1923 have since 1935 accounted for at least $1 / 5$ of the genes. The Ayrshire animals imported from Sweden accounted for 14-17 per cent of the genes in 1915-35, but only for 4,5-5,0 per cent in 1955-65. Ancestors of native or unknown origin accounted for over 21 per cent of the genes in 1915, but only for 3-8 per cent in 1945-65.

The relationship of the AI bulls to 7 prominent ancestors varied, on an average, between 2.4 and 12.6 per cent. There was a slight tendency for the degree of relationship to decrease with decreasing age of the bull categories.

The mean $F_{x}$ for $A I$ bulls born in 1939-44, 1945-49, 1950-54, 1955-59 and 1960-62 were $2.1,4.1,3.3,2.4$ and 2.3 per cent, respectively. Thus there was no significant trend in the development. Only 28 bulls $\left(3.6 \%\right.$ ) had an $\mathrm{F}_{x}$ of 9 per cent or more, over 90 per cent hăd less than 6 per cent.

The bull South Craib Snowball A 3399 (imported in 1923 from Scotland) was the individual influencing the breed mostly. His direct relationship to the cows increased from 1 per cent in 1925 to 14.8 per cent in 1965 . His relationship to the AI bulls in use in 1955 was 16.4 per cent and to those in use in 196012.4 per cent.

\section{Gewinnfunktionen - ein Hilffsmittel für die Planung von GEBRAUCHSKREUZUNGEN BEIM SCHWEIN}

\author{
F. FEwsoN. - Institut für Tierzüchtung und Tierhaltung der Universitä \\ Hohenheim - BRD.
}

V. JakUBFC. - Forschungsinstitut für Tierzucht in Uhrineves bei Prag - CSSR

Aufbauend auf den Arbeiten von Suтt (1964), Moav und Moav (1966, Breed. Poult. Sci., 7, 5) sowie MoAv (1966, Anim. Prod., 8, 193, 203, 365) wurden Gewinnfunktionen für die Reinzucht und Gebrauchskreuzung beim Schwein entwickelt. In der allgemeinen Gewinnfunktion für die Schweineproduktion wird mit einer variablen Erlöskomponente/Qualitäts-bzw.-abschläge/gerechnet, in die verschiedene Merkmale der Schlachtkörperqualität eingehen können. 
Die variablen Produktionskosten werden durch mehrere Merkmale der Mastleistung erfasst. Die variable Erlöskomponente und die variablen Produktionskosten werden zu einem Index für die Produktionsleistung zusammengefasst. Die variablen Reproduktionskosten ergeben sich aus den durchschnittlichen Sauenhaltungskosten, die von der Anzahl der aufgezogenen Ferkel je Jarhr ahbängen. Spezielle Gewinnfunktionen für verschiedene Formen von Gebrauchskreuzungen werden abgeleitet.

1. bei ausschliesslicher Annahme von additiver Genwirkung.

2. bei Annahme von additiver Genwirkung und durchschnittlicher Heterosiseffekte.

3. bei Annahme von additiver Genwirkung und durchschnittlicher Heterosiseffekte unter Einbeziehung der Nebenproduktion/Mastschweine in Vermehrungsbetrieben.

Anhand von Gewinnfunktionen werden Modellrechnungen über die Effektivität verschiedener Formen von Gebrauchskreuzungen durchgeführt. Als Ausgangspopulationen wurden 9 Zuchtlinien mit unterschiedlicher Produktions-und Reproduktionsleistung unterstellt, dahei wurde angenommen. dass zwischen der Fleischleistung und der Aufzuchtleistung negative Beziehungen bestehen. Für die verschiedenen Komponenten der Heterosiswirkung wurden durchsschnittliche Heterosiseffekte unterstellt.

Die wichtigsten Ergebnisse der Modellrechnungen sind :

1. Die Produktionsleistung der Ausgangslinien wirkt sich inviel stärkerem Ausmass auf die Rentabilität der Schweineproduktion bei Gebrauchskreuzungen aus als die Reproduktionsleistung.

2. Überragt eine Zuchtlinie alle anderen in der Produktionsleistung wesentlich, so kann durch Reinzucht mit dieser Zuchtlinie der höchste Gewinn erzielt werden.

Sofern verlässliche Informationen über das Leistungsniveau der vorhandenen Zuchtlinien zur Verfügung stehen, sollte eine Vorauswahl erfolgversprechender Zuchtlinien für die anschliessende Leistungsprüfung mit Hilfe von Gewinnfunktionen vorgenommen werden.

\title{
RESULTS OF CROSSBREEDING PIGS IN CZECHOSLOVAKIA
}

\author{
RUDOrF SILER. — Research Institute of Animal Production, Uhrineves near \\ Prague, Czechoslovakia.
}

Crossbreeding pigs is now a common practice in Czechoslovakia as compared with the situation 10-12 years ago. There are two native breeds, $i$. e. Czech Large White (CLW), and Black Spotted Prestice (BSP), and three imported breeds, i. e. Land-race (L), Large Black (LB), and Piétrain $(P)$. 57 per cent of the total number of boars are used for commercial crossbreeding. The most popular comhination is $C L W \times L B$. The use of this combination is decreasing in recent years in favour of crossing $C L W$ dams with $L$ boars.

As regards research work only mentioning results from recent years, an experiment with reciprocal crossing including $C L W, L, L B, B S P$, and $P$ was completed. No maternal effects and no significant differences between the reciprocal crosses were found. The amount of heterosis for various characters was also estimated. The largest heterotic effect was in reproductive characters $(7-10 \%)$; a medium one in fattening ahility $(2-4 \%)$ was found, and none in carcass value.

$L$ boars are mostly used for improvement of $C L W$ meat quality. The crossbred progeny shows a better carcass quality than purebred CLW. Results of a special experiment indicated that it is best to fatten these crossbreds to a weight of $100-110 \mathrm{kgs}$.

The performance of crossbreds from crossbreeding, criss-crossbreeding, and rotational crossbreeding was evaluated by using $C L W, L$, and $L B$, As regards litter size, the combination $(C L W \times L) \times L B$ was found to be the most effective one.

The general possibilities of predicting the efficiency of crossbreds on the basis of knowledge at the original parental populations were also examined, and contemporaneous views regarding the evaluation of heterotic effect were evaluated. 